\title{
Microbes profile from blood stream infection cases and their relationship to those of environment in Neonatal unit
}

\author{
Lucky H. Moehario, ${ }^{1}$ Enty Tjoa, ${ }^{2}$ Rinawati Rohsiswatmo, ${ }^{3}$ Sarah R. Nursyirwan ${ }^{3}$ \\ ${ }^{1}$ Department of Microbiology, Faculty of Medicine, Universitas Indonesia, Jakarta, Indonesia \\ ${ }^{2}$ Department of Microbiology, Faculty of Medicine, Catholic University of Atma Jaya, Indonesia; Residence in Clinical \\ Microbiology Specialist Program Faculty of Medicine, Universitas Indonesia, Jakarta, Indonesia \\ ${ }^{3}$ Department of Pediatrics, Faculty of Medicine, Universitas Indonesia - Neonatal Unit Cipto Mangunkusumo Hospital, \\ Jakarta, Indonesia
}

\begin{abstract}
Abstrak
Latar Belakang: Infeksi Aliran Darah (IAD) terkait infeksi rumah sakit atau infeksi nosokomial telah menyebabkan beban kesakitan, kematian dan biaya yang cukup besar. Penelitian ini bertujuan untuk menilai kejadian infeksi Rumah SakitIAD pada neonatus dengan berat lahir 1000-2000 g yang dirawat di Unit Neonatal RSUPNCM, Jakarta, selama 4 bulan (Oktober 2010 - Januari 2011), dan melihat kemungkinan keterkaitan mikroba lingkungan dengan kejadian IAD di unit Neonatal.

Metode: Subjek penelitian adalah neonatus (berat lahir 1000-2000 g) dengan klinis sepsis dan telah dirawat di rumah sakit selama minimal 48 jam, tidak ditemukan fokal infeksi yang jelas dan menggunakan kateter intra-vascular. Pada subjek penelitian dilakukan pemeriksaan biakan darah dengan dua spesimen darah yang diambil dari dua kali pengambilan darah. Biakan yang positif dilanjutkan dengan proses identifikasi dan uji sensitivitas terhadap antibiotika. Pemeriksaan biakan dari spesimen lingkungan unit perawatan dan spesimen klinis lainnya juga dilakukan.

Hasil: Dari 29 neonatus dengan 39 episode sepsis, 5 biakan darah positif, dengan isolat: Enterobacter asburiae (2), Enterobacter cloacae (1), Pseudomonas aeruginosa (1) dan Klebsiella oxytoca (1). Infeksi rumah sakit-IAD yang terkonfirmasi dengan hasil laboratorium (laboratory confirmed) adalah 12,8\% (5/39), sementara rate IAD adalah 1,46 per 1000 hari pemasangan kateter selama 4 bulan (Oktober 2010-Januari 2011). Spesies bakteri yang sama juga ditemukan dari lingkungan dan spesimen klinis lainnya. Analisis dari antibiogram masing-masing isolat dari darah dan lingkungan menunjukkan kemiripan dan pada beberapa strain identik yaitu strain E. asburiae, dan strain P. aeruginosa.

Kesimpulan: Bakteri yang berperan sebagai penyebab IAD terkait rumah sakit di Unit Neonatal RSUPNCM adalah kelompok bakteri Gram negatif. Walaupun rate IAD pada penelitian memberikan hasil yang cukup rendah, namun berdasarkan perbandingan profil antibiogram isolat dari darah dan lingkungan menunjukkan profil antibiogram yang mirip bahkan identik. (Med J Indones 2012;21:32-7)
\end{abstract}

\begin{abstract}
Background: Hospital Acquired Infection (HAI)-Blood Stream infection (BSI) cause considerable morbidity, mortality and health care costs. This study aimed to assess the HAI-BSI in neonates with birth weight 1000-2000 g in Neonatal Unit Cipto Mangunkusumo National Hospital (RSUPNCM), Jakarta, during 4 months period (Oct 2010-Jan 2011), and to review the possibility of sources and transmission of environment microbes to the presence of HAI-BSI in the unit.
\end{abstract}

Methods: Subjects of this study were neonates (birth weight 1000-2000 g) with clinically sepsis and within 48 hours or more being hospitalized, no clearly focal infection detected, with catheter lines. Two blood specimens from two separate venipunctures, drawn simultaneously, were cultivated. Identification and antimicrobial susceptibility tests were performed for each isolates. Cultures from environment in the unit and other suspected clinical specimens were also examined.

Results: From 29 neonates with 39 episodes of sepsis, 5 positive isolates from blood cultures were obtained i.e. Enterobacter asburiae (2), Enterobacter cloacae (1), Pseudomonas aeruginosa (1) and Klebsiella oxytoca (1). The laboratory confirmed HAI-BSI was $12.8 \%$, and HAI-BSI rate was 1.46 per 1000 catheter line days during 4 months period (Oct 2010-Jan 2011). Cultures performed for environment specimens gave yield some species which were as those from clinical specimens. Antibiogram analysis showed those of environment isolates i.e E. asburiae and P. aeruginosa shared similarity to those of neonates' blood isolates.

Conclusion: Gram-negative bacteria were responsible to the occurrence of HAI-BSI in the Neonatal Unit RSUPNCM. Despite of low HAI-BSI rate found in this study, analysis of antibiogram profiles of the isolates originated from neonates' blood and environment strongly suggested that cross infection was present in the unit. (Med J Indones 2012;21:32-7)

Keywords: Antibiogram, blood stream infection, hospital acquired infection, neonates 
"Do patient no harm" is a phrase for every hospital worldwide. Today, people often get an infection during their stay in hospital and these situation are called Hospital Acquired Infection (HAI) ${ }^{1}$ or more familiar with old terms "Nosocomial Infection". Patients almost certainly have one or more of their natural protective mechanisms breached, for example, inserting an intravenous line, undergoing surgery, or other means which interfere intact skin barrier. There are many ways for opportunistic microbes to establish infections. Not to mention that patient will acquire colonization by certain microbes from close contact with healthcare workers, other patients, medical devices and others. Most of colonization occurs at the skin and/or mucosal surfaces and gastrointestinal tract. There was a report about gastrointestinal tract of ICU's patients became a reservoar of multidrug resistance Acinetobacter baumanii. ${ }^{2}$ Bacteria are the most common cause of HAI, however, recent trends show an increase of incidence in fungal infections. ${ }^{3,4}$

According to $\mathrm{CDC} / \mathrm{NHSN}$ surveillance definition, there are 13 major types of HAI, one of them is Blood Stream Infection (BSI). ${ }^{1}$ HAI-BSI cause considerable morbidity, mortality and health care costs. About 20$30 \%$ preterm neonates hospitalized may have two or more HAI episodes. ${ }^{5}$

In Indonesia, most common causes of neonates' death were as follow: for neonates aged 0-6 days i.e. respiratory disorder (37\%), prematurity (34\%) and sepsis (12\%); for neonates aged 7-28 days i.e. sepsis $(20.5 \%)$, congenital abnormality (19\%), pneumonia (17\%), respiratory distress syndrome (14\%) and prematurity (14\%). ${ }^{6} \mathrm{~A}$ report from Cipto Mangunkusumo National Hospital (RSUPNCM) revealed infection was the most prevalent cause of death among neonates $(30 \%)$, both in wards and intensive care. ${ }^{7}$ Overall, mortality rate of neonates in Indonesia was higher in comparison to Singapore, Malaysia and Thailand. ${ }^{8,9}$ In 2009, BSI rate was found $52.31 \%$ and $29.96 \%$ for neonates with birth weight 1,000-1,499 $\mathrm{g}$ and 1,500-1,499 g subsequently. ${ }^{7}$ The high incidence of BSI in this group of neonates needs special evaluation to find the etiology, and so prevent of becoming worse.

This study aimed to assess the HAI-BSI in neonates with birth weight 1000-2000 g in Neonatal unit RSUPNCM during 4 months period (Oct 2010-Jan 2011), and to review the role of the pathogen and the environmental microbes as the cause of HAI-BSI.

\section{METHODS}

A study was conducted on neonates with birth weight 1000-2000 g, which have been diagnosed clinically sepsis, within 48 hours or more being hospitalized in Neonatal Unit of RSUPNCM, with no clear focal infection and used catheter line (peripheral and/ or central line catheter). CDC/NHSN surveillance definition of health care-associated infection criteria were used. ${ }^{1}$

Two blood specimens from two separate venipunctures were drawn simultaneously or within 48 hours and cultivated in BACTEC PAED ${ }^{\circledR}$ bottles. Inoculations on MacConkey and blood agar were performed when growth of microbes was detected, followed by identification of bacteria species using coagulase, catalase, manitol tests and API STREP ${ }^{\circledR}$ for Grampositive bacteria. Oxidase test, API $20 \mathrm{E}^{\circledR}, 20 \mathrm{NE}^{\circledR}$ were used for Gram-negative bacteria. Antimicrobial Susceptibility Tests (AST) were performed for each isolates using Clinical and Laboratory Standards Institute (CLSI) as reference. ${ }^{10}$

Objects suspected to be the sources of infection as shown in Table 1 were also examined. All of the specimens were inoculated on blood agar, and continued with identification and AST as above. All microbiology procedures were carried out in Clinical Microbiology Laboratory of Medical Faculty University of Indonesia (CML-FMUI). The sampling area in Neonatal Unit was shown in Figure 1.

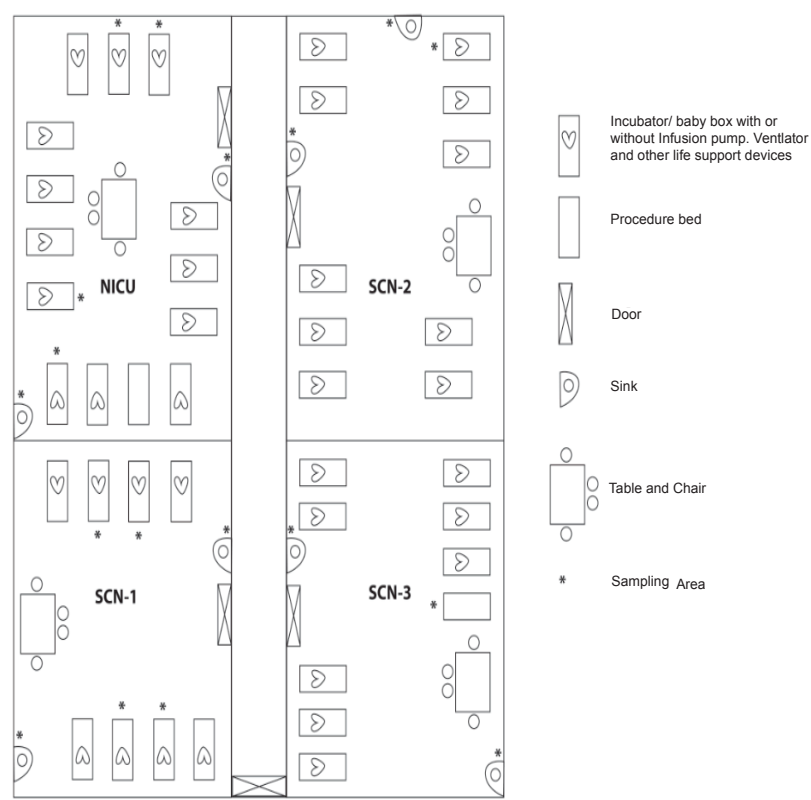

Figure 1. Neonatal Unit at RSUPNCM

Neonatal unit is located in the third floor of PJT Building, RSUPNCM. The unit is divided into 4 main areas as follow: Neonatal Intensive Care unit (NICU), Special Care Nursing (SCN) 1, SCN 2, SCN 3. Another SCN, that is SCN-4 where special care and invasive procedures are not needed, is located in a separate building. Our investigation covered all areas except SCN-4. 


\section{RESULTS}

A total of 3410 catheter days was observed in neonates with birth weight 1000-2000 g in the Neonatal unit and five cases were contracted HAI-BSI. In other words, HAI-BSI rate was 1.46 per 1000 catheter days during the period of study from Oct 2010 to Jan 2011 (see Table 2). Further, from 39 episodes of sepsis, 5 pathogenic microorganisms were isolated. All of the isolates were Gram-negative bacteria i.e. Enterobacter asburiae (E. asburiae) (2 isolates), Enterobacter cloacae (E.cloacae) (1 isolate), Klebsiella oxytoca (K.oxytoca) (1 isolate), and Pseudomonas aeruginosa (P.aeruginosa) (1 isolate) (Table 1). In addition to those pathogens, 16 isolates originated from environment and clinical specimens were also isolated and particularly analyzed for their possible roles as exogenous sources of HAI-BSI using antibiogram similarity (see Table 1, 3 and 4$)$.

Both isolates of E. asburiae from two neonates' blood showed identical antibiogram patterns, suggesting these isolates were identical strains, while one isolate from humidifier (liquid) showed some degree of similarity in its antibiogram profile with the two from blood (Table3). The two isolates of E. asburiae of blood were in fact isolated from two different neonates in the NICU room (see Figure 1) within a day interval. This situation strongly suggested there was cross infection in the unit.

Table 2. Catheter days of neonates (1000-2000 g) during Oct 2010-Dec 2011 and HAI-BSI cases per months

\begin{tabular}{ccc}
\hline Months/Year & $\begin{array}{c}\text { Catheter days of neonates } \\
\text { with birth weight 1000-2000 gram }\end{array}$ & $\begin{array}{c}\text { HAI-BSI } \\
\text { cases }\end{array}$ \\
\hline October 2010 & 447 & 3 \\
November 2010 & 1048 & 1 \\
December 2010 & 902 & 1 \\
Januari 2011 & 1013 & 0 \\
Total & 3410 & 5 \\
\hline
\end{tabular}

Table 1. Bacteria isolated from blood of neonates (1000-2000 g) with HAI-BSI and environment*

\begin{tabular}{|c|c|c|c|}
\hline Organisms & Specimens & Specimens collection & Patients' outcome \\
\hline E. asburiae & Blood & venipuncture & Live \\
\hline E. asburiae & Blood & venipuncture & Live \\
\hline E. asburiae & Humidifier liquid of incubator & needle-syringe steril & - \\
\hline E. cloacae & Blood & venipuncture & Live \\
\hline E.cloacae & Humidifier liquid of incubator & needle-syringe steril & - \\
\hline E.cloacae & Pus from bogota bag's patient with colostomy & swab & - \\
\hline K.oxytoca & Blood & venipuncture & Live \\
\hline K.oxytoca & Incubator's attached gloves & swab & - \\
\hline P. aeruginosa & Blood & venipuncture & Live \\
\hline P. aeruginosa & Tap water's filter & swab & - \\
\hline P. aeruginosa & Tap water's filter & swab & - \\
\hline P. aeruginosa & Tap water & sterile container & - \\
\hline P. aeruginosa & Tap water & sterile container & - \\
\hline P. aeruginosa & Tap water & sterile container & - \\
\hline P. aeruginosa & Tap water & sterile container & - \\
\hline P. aeruginosa & Tap water & sterile container & - \\
\hline P. aeruginosa & Tap water & sterile container & - \\
\hline P. aeruginosa & Tap water & sterile container & - \\
\hline P. aeruginosa & Tracheal aspirate of one patient with pneumonia & aspirate & - \\
\hline P. aeruginosa & Buttons of infusion pump no. 13 & swab & - \\
\hline P. aeruginosa & Skin of neonates (hand) & swab & - \\
\hline
\end{tabular}

* Microorganisms shown were those of environment, which had counterpart from blood. Other microorganisms isolated from environment were not reported. 

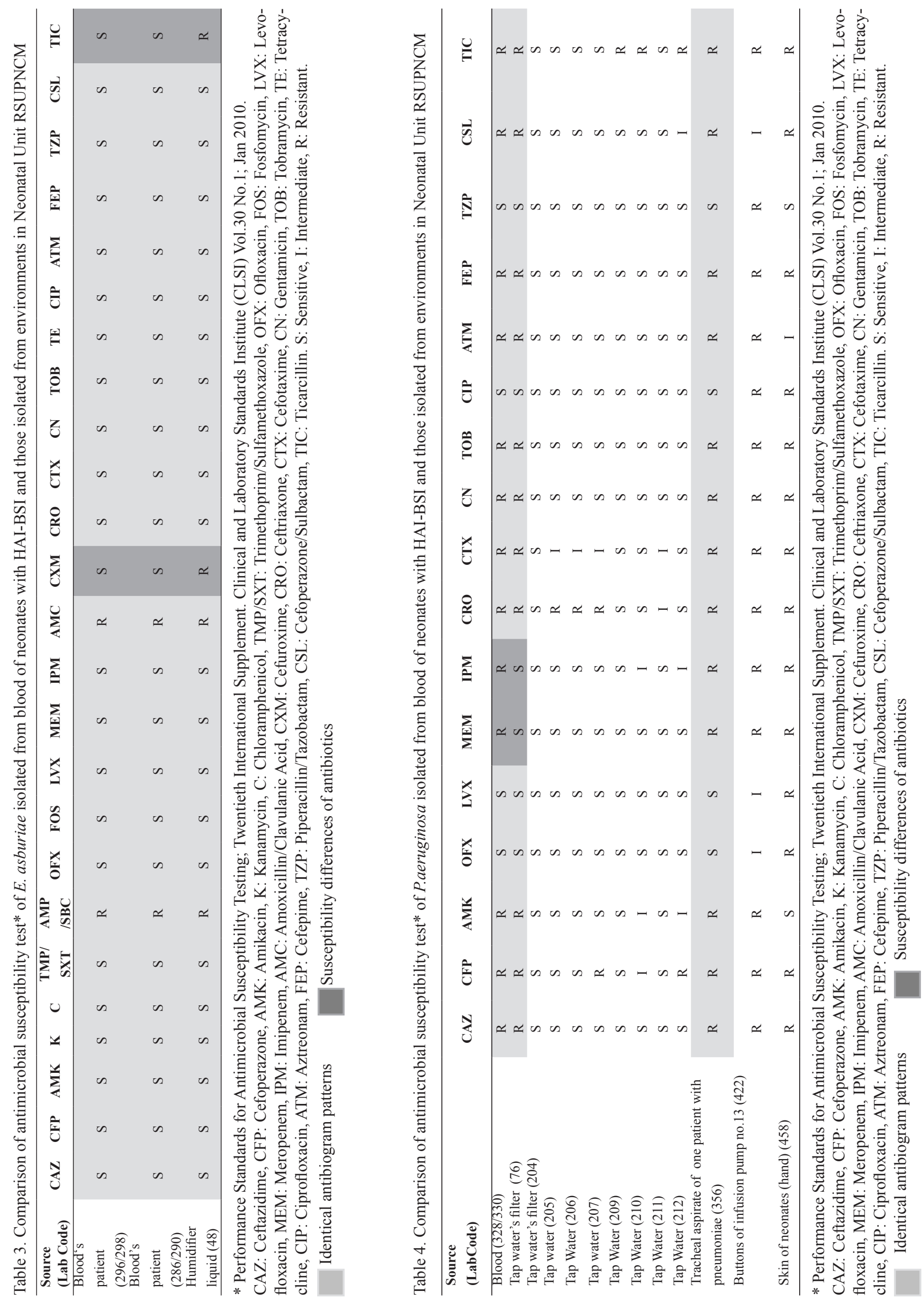


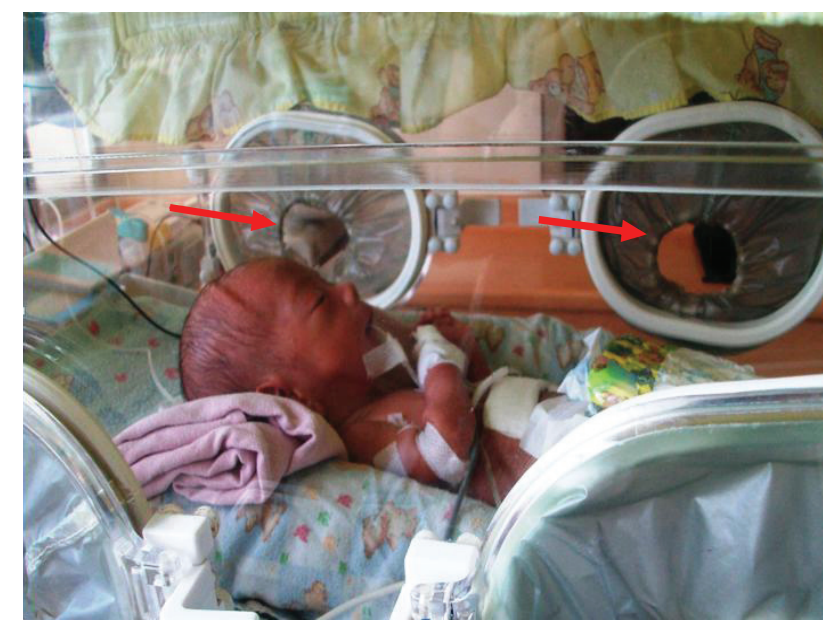

Figure 2. Incubator's attached gloves (red arrow)

P. aeruginosa isolated from blood (328/330) and tracheal aspirate (356), from different patients in 3 weeks interval showed identical antibiograms profile, suggesting those were the same strains which present and colonized the unit (see Table 4); these clinical specimens originated from neonates in SCN 1 (Figure 1). Most of $P$. aeruginosa isolates from water were susceptible to almost all antibiotics tested, suggesting these isolates were not playing a role in the HAI-BSI cases. One isolate (76) from water, however, showed high similarity of its antibiogram to those of two isolates from blood (328/330) and tracheal aspirate (356) (Table 4), suggesting they might share clonality. We also found $P$. aeruginosa from the buttons of an infusion pump located in the NICU room (Figure 1) and hands of neonates whom placed in 4 different rooms (Figure 1). Antibiograms of this isolate showed three or more differences in their susceptibility (Table 4). However, their role in the transmission of infection could not be excluded yet. Further studies employing molecular approach such as genotyping are more than needed to confirm of whether these $P$. aeruginosa isolates were the same strain. Molecular typing is needed as well for the E. asburiae from neonates' blood.

E. cloacae isolated from blood and humidifier liquid shared some similarity in their antibiogram patterns, except for three antibiotics i.e. Kanamycin, Trimethoprim/Sulfamethoxazole and Cefuroxime. Isolates from bogota bag showed resistant to all of antibiotics tested except Amikacin (data not shown). Antibiogram of $K$. oxytoca isolated from blood patient and incubator's attached gloves (Figure 2) were different in more than three antibiotics tested (data not shown). Based on antibiogram profiles, most probably E. cloacae and K. oxytoca were not sharing clonality to those from neonates' blood.

\section{DISCUSSION}

Our study showed that Gram-negative bacteria were the etiology of laboratory confirmed-BSI, while other centers reported Gram-positive as well as Gramnegative microbes and fungi. ${ }^{11,12} E$. cloacae as the cause of bacteremia in neonatal intensive care settings were also reported in some developed countries such as in USA and responsible for significant morbidity and mortality especially in very low birth weight infants. ${ }^{13}$ A study conducted in Guatemala showed that Gram-negative bacteremia was prominent in neonates delivered by caesarian section, and those exposed to some intravenous drugs and other invasive procedures. ${ }^{14}$ In addition, the study found that the water system in the hospital was contaminated with fecal coliform and that seemed responsible to the colonization of neonates' skin by Gram-negative bacteria. ${ }^{14}$ In our study, we also analyzed the tap water in the NICU, SCN 1, 2 and 3 (Figure 1), and the results showed an elevation of total and fecal coliform bacteria. These suggested fecal contamination in the source of water, which increase risk factors for health care personnel and/or the babies to be colonized. Our preliminary study of the genome profile of the environmental microbes, Acinetobacter $s p$, and the same microbes isolated from neonates with BSI indicate close genetic relationship among them (data not shown).

Bathing the babies during hospitalization is also one important factor to decrease the risk factors for endogenous source of infection despite hypothermia issues. In this study, samplings from the environment including the skin of neonates were also performed. The results showed enteric microorganisms, Pseudomonas sp. and Acinetobacter sp. colonized the neonates' skin (data not shown). These neonates would most probably face risks of infection during invasive procedures particularly if antiseptic procedures were not adequate.

A multicenter study in USA reported the BSI rate was 5.1 per 1000 umbilical-or central-catheter days for more than $1500 \mathrm{~g}$ birth-weight group. ${ }^{5}$ According to the National Healthcare Safety Network, BSI rate was 3.1 up to 6.4 per $1,000 \mathrm{CVC}$ days in NICUs. ${ }^{12}$ In India, 1.3 per 1000 line days was reported as Catheter Associated Blood Stream Infection. ${ }^{15}$ The HAI-BSI rate observed in our study was actually low. However, the HAI-BSI rate would be more representative if the study had been conducted in a longer period of time. This rate was not intended to be compared to other units elsewhere, since every unit may have different local conditions.

The analysis of antibiogram profiles of isolates from neonates' blood, environments and other clinical 
samples strongly suggested the occurrence of cross infection in the Neonatal unit with strain of E. asburiae as well as $P$. aeruginosa. Some strains of environment bacteria shared some degree of similarity in their antibiograms to the ones from the neonates, suggesting cross infection was present in the unit. Modes of transmission of environment bacteria responsible for the occurrence of HAI-BSI were also indicated. Confirmation of the genetic relationship between these microbes of environment and the pathogens is necessary since the information can be used to trace the source and distribution in order to prevent HAI.

The HAI-BSI rate in the Neonatal Unit was within a low range, however this condition should be maintained low and, if possible should be decreased to zero by first of all having medical personnel comply the hand hygiene and always carry out correct antiseptic procedures prior to any invasive procedures.

\section{Acknowledgment}

This study was funded by RSUPNCM, Jakarta, Indonesia. We thanked Tjahjono D. Gondhowiardjo, MD, Ph.D for his effort in putting together the funding from the institution to conduct the investigation.

\section{REFERENCES}

1. Horan TC, Andrus M, Dudeck MA. CDC/NHSN surveillance definition of health care-associated infection and criteria for specific types of infections in the acute care setting. Am J Infect Control. 2008;36:309-32.

2. Agusti C, Pujol M, Argerich MJ, Ayats J, Badia M, Dominguez MA, et al. Short-term effect of the application of selective decontamination of the digestive tract on different body site reservoir ICU patients colonized by multi-resistant Acinetobacter baumannii. J Antimicrob Chemother. 2002;49(1):205-8.
3. Hardy PS. Nosocomial infection in human microbiology. USA: Taylor \& Francis Inc.; 2002. p. 182-3.

4. Abelson JA, Moore T, Bruckner D, Deville J, Nielsen K. Frequency of fungemia in hospitalized pediatric inpatient over 11 years at a tertiary care institution. Pediatrics. 2005;116(1):61-7.

5. Clark R, Powers R, White R, Bloom B, Sanchez P, Benjamin DK. Nosocomial infection in the NICU: a medical complication or unavoidable problem? J Perinatol. 2004;24:382-8.

6. Riset kesehatan dasar 2007. Jakarta: Badan Penelitian dan Pengembangan Kesehatan Departemen Kesehatan RI; 2008 [cited 2009 Dec 16]. Available from: www.litbang.depkes. go.id/riskesdas/index.htm. Indonesian.

7. Laporan fetomaternal Rumah Sakit Cipto Mangunkusumo [unpublished report]. 2009. Indonesian.

8. Brinkhoff $\mathrm{T}$. Infant mortality rates of the world [Internet]. [cited 2009 Mar 31]. Available from: http://world.bymap. org/InfantMortality.html

9. Survei demografi dan kesehatan Indonesia (SDKI) tahun 2007: angka kematian neonatus, bayi dan balita tahun 2007. Jakarta: Badan Pusat Statistik; 2008. Indonesian.

10. Clinical and Laboratory Standards Institute. Performance standards for antimicrobial susceptibility testing; twentieth international supplement. Qual Health Care. 2010;30(1).

11. Tan CC, Zanariah Y, Liam KI, Balan S. Central venous catheter-related blood stream infections: incidence and an analysis of risk factors. Med $\mathrm{J}$ Malaysia. 2007;62(5):370-4.

12. Curry S, Honeycutt M, Goins G, Gillian C. Catheterassociated bloodstream infection in the NICU: getting to zero. Neonatal Netw. 2009;28(3):151-5.

13. Cordero L, Rau R, Taylor D, Ayers LW. Enteric gramnegative bacilli bloodstream infection: 17 years' experience in a neonatal intensive care unit. Am J Infect Control. 2004;32(4):189-96.

14. Pegues DA, Arathoon EG, Samayoa B, Del Valle GT, Anderson RL, Riddle CF, et al. Epidemic gram-negative bacteremia in a neonatal intensive care unit in Guatemala. Am J Infect Control. 1994;22(3):163-71

15. Rao S, Alladi A, Das K, Cruz AJ. Medium and long term central venous access in children. Indian Pediatr. 2003;40:41-4. 